DOI: 10.17707/AgricultForest.63.1.20

\author{
Alexander IVANOV, \\ Anastasia ERMOLAEVA, Julia YUDICHEVA ${ }^{I}$
}

\title{
PATTERNS OF SETTLEMENT OF MYCORRHIZA-FORMING-FUNGI IN THE BROAD-LEAVED FORESTS OF VOLGA FOREST-STEPPE
}

\section{SUMMARY}

Species composition of mycorrhiza-forming fungi of the class Agaricomycetes of broad-leaved forests of the Volga forest-steppe in the area of the Penza region was studied. Those forests have the richest species composition of the fungi of the studied group among forest community of the region in which they are presented by 134 species. The most common species, identified in all studied associations, are Amanita crocea, A. pantherina, A. phalloides, A.rubescens, A.vaginata, B. reticulatus, Clytopilus prunulus, Hebeloma sinapizans, Lactarius quietus, L. piperatus, L. vellereus, , Neoboletus erythropus Russula foetens, $R$. delica, $R$. lutea, $R$. pseudointegra, Xerocomellus chrysenteron. Due to the diversity of soil and hydrological conditions, the settlement of the related symbiotrophic species seems rather complex. Impoverished species composition of the symbiotrophic species is typical for Quercus robur+Tilia cordata associations on acid soils with $\mathrm{pH}$ from 4.3 to 4.5 and much richer for the broad-leaved forests on soils with $\mathrm{pH}$ of 6-7. The forest-steppes in flood plains of the water-collecting area of the Volga river are easternmost point of settlement of South-European nemoral species. Therefore, they are important from the point of view of the protection of rare species of agaricomycetes.

Keywords: calciphiles, mycorhizal symbiosis, rare species, broadleaved forests, symbiotrophic species.

\section{INTRODUCTION}

Among of forest communities of Russian Plain the broad-leaved forests are the least studied regarding mycorrhiza-forming fungi. Brief information of them is represented in the publications of Ganzha, Bedenko, Svetashevoy, Rebriyeva and others $(1960,1979,2015)$. They have been studied concerning the Volga forest-steppe by Ivanov (1987). However, to date, previously published materials have been significantly clarified and supplemented. The study of the mycorrhiza-forming fungi is critical from the understanding of

\footnotetext{
${ }^{1}$ Alexander Ivanov (corresponding author: rcgekim@mail.ru), Anastasia Ermolaeva, Julia Yudicheva Penza State Agricultural Academy, Penza, 30 Botanicheskaya str. 440014 RUSSIA Notes: The authors declare that they have no conflicts of interest. Authorship Form signed online.
} 
biological features of Qercus robur point of view which is the main forest forming species in these conditions.

\section{MATERIALS AND METHODS}

Study results conducted from 1978 to 2016 in broad-leaved forests of the Volga forest-steppe in the area of the Penza region were used as a basis for this paper. This area is located about $600 \mathrm{~km}$ south-west of Moscow (fig.1).

The climate of the considered area is moderately continental with recurrent droughts. The average temperature in July is $+19^{\circ} \mathrm{C}-+19.5^{\circ} \mathrm{C}$, in January - $12,5^{\circ} \mathrm{C}--13^{\circ} \mathrm{C}$. The amount of precipitation in the different regions of the area is from 300 to $650 \mathrm{~mm}$ per year (Zhakov, 1970).

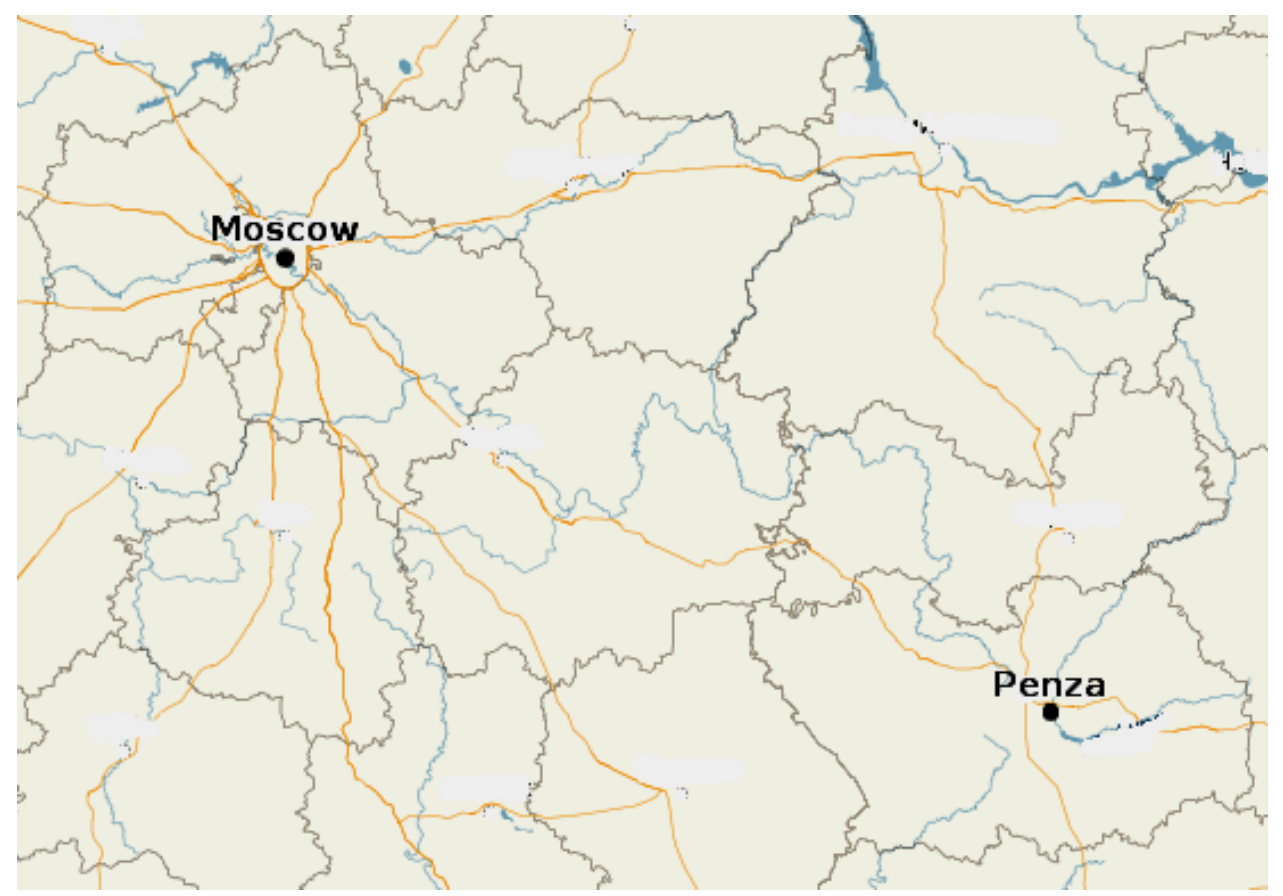

Figure 1. Geographical position of the Penza region

The relief throughout majority of the studied area is flat with intense erosion partitioning (?). Grey forest soils and salt washed black soils prevail in a soil cover. Underlying parent materials are represented by sands, flasks, noncalcareous and calcareous clay (Milkov, 1953).

Vegetation has a typical forest-steppe appearance. Forests are presented by separate areas of different sizes surrounded by agricultural holdings. Native types of forest vegetation are pine and broad-leaved forests. Betula pendula Roth(Author names for all species after first appearance in the text and Populus tremula L.forests are also widespread. Mycological studies were conducted for Broad-leaved forests mainly composed of Qercus robur L., Tilia cordata Mill. 
and Corylus avellana L. (. Carex pilosa Scop. and Aegopodium podagraria L. prevail in a grass cover. Studied forests were cut down during the Second World War. They are of the same age (65-70 years) and have a vegetative origin.

We have studied species composition of mycorrhiza-forming fungi in the studied area from 1978 to 2016 by us. Herborization and identification of collected samples of the fungi were conducted by commonly used methods, using a light microscopy to study the morphology of the microstructures (Bondarcev, Zinger, 1950; Moser, 1978; Funga Nordica, 2008). Monographic reports were used to identify certain taxa Bakker, 2005; Muñoz,2005 et al.).

Censuring of fruit body and species variety of fungi was conducted by route and stationary methods. We have paved four routes taking into account the diversity of forest growth conditions (fig 2). The routes were visited in summer and autumn periods weekly because climatic conditions in these periods are favorable for growing fruits bodies. We have carried out the route studies from 1984 to 2016.

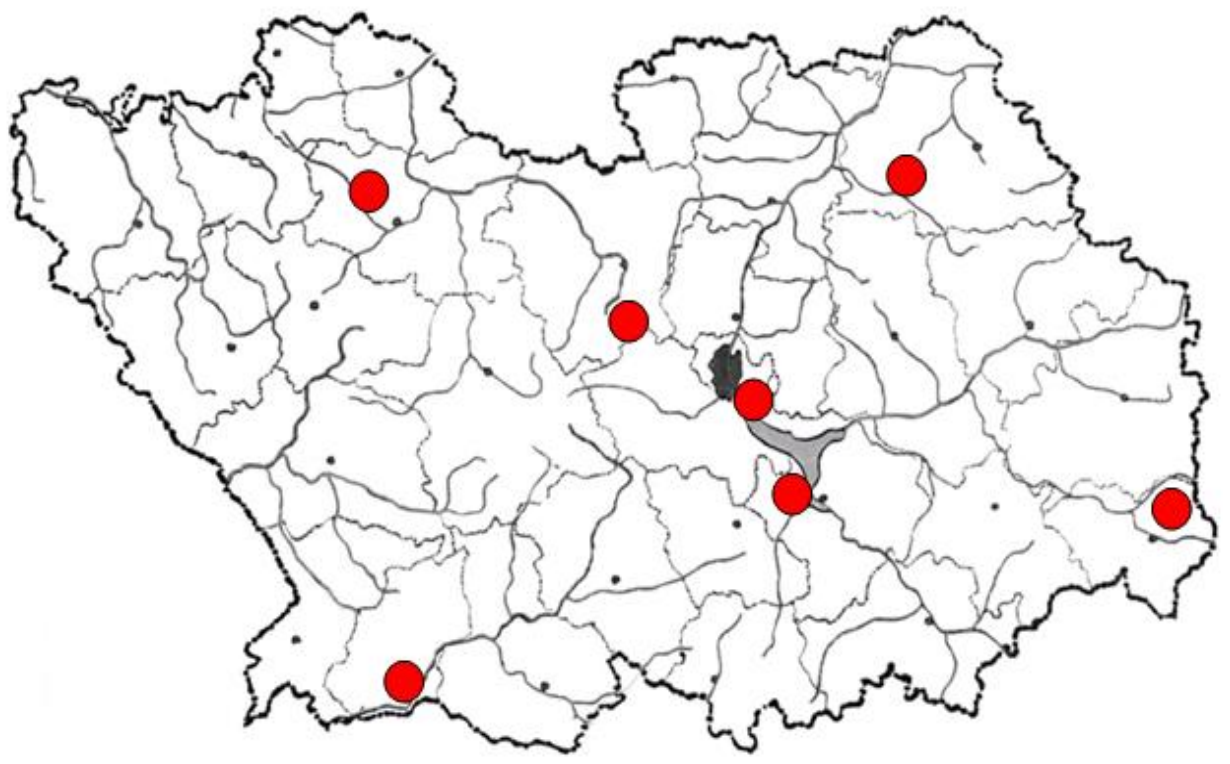

Figure 2. Venues route and stationary studies IT is not cear what is on the map. More precise Explanation should be given

The route studies were supplemented with stationary studies. We had laid four testing transects of $10 \times 100 \mathrm{~m}$ to register species composition of mycorrhizaforming fungi and yield of their fruit bodies from 2007 to 2009. Fruit bodies were collected with an interval of five days, dried and weighed. Drying of the fungi was carried out in the New Zealand dehydrator Ezidri snackmaker FD500 manufactured by Hydroflou indastris. The need for the drying was determined by the fact that water content in fruit bodies of fungi is not the sane in different 
weather. Therefore, drained weight is a more objective index of biological productivity as compared with the weight of fresh fungi.

Characteristics of plant associations, soils, species composition and productivity of fungal fruit-bodies are given in table 1 . Determination of $\mathrm{pH}$ of a salt extract of soil was carried out by means of $\mathrm{pH}$ meter $\mathrm{pH}-410$ manufactured by NPKF "Akvilon" (Russia). The relevance of the names of fungi and their accuracy has been verified according to the database Index fungorum (2016).

Table 1. Species diversity and yields of Agaricomycetes mycothallus in broad-leaved forests on different types of soil

\begin{tabular}{|c|c|c|c|c|c|}
\hline \multirow{2}{*}{ Association name } & \multicolumn{3}{|c|}{ Soil characteristic } & \multicolumn{2}{c|}{$\begin{array}{c}\text { Mycobiota } \\
\text { characteristic }\end{array}$} \\
\cline { 2 - 6 } & Soil variety & $\begin{array}{c}\text { Underlying } \\
\text { rock }\end{array}$ & $\begin{array}{c}\mathrm{pH} \text { of } \\
\text { salt } \\
\text { extract }\end{array}$ & $\begin{array}{c}\text { Number of } \\
\text { species }\end{array}$ & $\begin{array}{c}\text { Yield of } \\
\text { fruiting } \\
\text { body, g }\end{array}$ \\
\hline $\begin{array}{c}\text { Quercus robur+tilia } \\
\text { cordata- Aegopodium } \\
\text { podagraria }\end{array}$ & $\begin{array}{c}\text { heavy loam } \\
\text { gray forest } \\
\text { soil }\end{array}$ & $\begin{array}{c}\text { Noncalcare } \\
\text { ous clay }\end{array}$ & $4.3-4.5$ & 12 & 763 \\
\hline $\begin{array}{c}\text { Quercus robur+tilia } \\
\text { cordata-Carex pilosa }\end{array}$ & $\begin{array}{c}\text { light sandy } \\
\text { loam gray } \\
\text { soil }\end{array}$ & Flask & $4.2-4.5$ & 18 & 3065 \\
\hline $\begin{array}{c}\text { Quercus robur+tilia } \\
\text { cordata- Carex pilosa }\end{array}$ & $\begin{array}{c}\text { light loam } \\
\text { gray forest } \\
\text { soils }\end{array}$ & Marl & $6.5-7$ & 25 & 4950 \\
\hline $\begin{array}{c}\text { Quercus robur+tilia } \\
\text { cordata-Carex pilosa+ } \\
\text { heterogerbosa }\end{array}$ & $\begin{array}{c}\text { sandy loam } \\
\text { gray forest } \\
\text { soil }\end{array}$ & Sand & $6-6.5$ & 27 & 4944 \\
\hline
\end{tabular}

\section{RESULTS AND DISCUSSION}

Among the forest communities of the examined region, the broad-leaved forests have the richest species composition of mycorrhiza-forming fungi. They are presented by 134 species, most of them are connected with symbiotic relationships with the main forest-forming species Qercus robur. 85 species are connected with Pinus silvestris L., 60 with Betula pendula, 39 with Populus tremula, 46 with Alnus glutinosa (L.) Gaertn. (Ivanov, 1987; 1992; 1994). However, the variety of species diversity of symbiotrophic species is not combined with a large-statured abundance. According to the attendance of testing areas, the average yield of fruit bodies of mycorrhiza-forming fungi in boardleaved forests is lower than in other types of forests. There is only $36805 \mathrm{~g} / \mathrm{ha}$ in terms of the equivalent amount of dry substance, but in pine forests, the value is $55520 \mathrm{~g} / \mathrm{ha}$ and $104700 \mathrm{~g} / \mathrm{ha}$ in birch forest (Ivanov, 1992).

In the present research work the volume of a trophic group of symbiotrophic species is understood in accordance with the (Tedersoo et al., 2010). Most of its fungi in broad-leaved forests of the studied area are associated with Qercus robur which is the only highly mycotrophic species. Very few of 
them form mycorrhizas with Tilia cordata (Cortinarius rigens Fr., Neoboletus erythropus (Pers.) C. Hahn, Russula aurea Pers, R.delica Fr. and Corylus avellana (Lactarius pyrogalus (Bull.) Fr., L.volemus (Fr.) Fr.) as evidenced by observations in pure stands of the last-mentioned.

The most common species, identified in all routes and most of testing area, are Amanita crocea (Quél.) Singer, A. pantherina (DC.) Krombh., A. phalloides (Vaill. ex Fr.) Link, A. rubescens Pers, A.vaginata(Bull.) Lam., Boletus reticulatus Schaeff., Clitopilus prunulus $\mathrm{P}$. Kumm, Hebeloma sinapizans (Paulet) Gillet, Lactarius quietus (Fr.) Fr., L. piperatus (L.) Pers., L. vellereus (Fr.) Fr, Neoboletus erythropus, Russula foetens Pers., R. delica, R.risigallina (Batsch) Sacc., R. pseudointegra Arnould \& Goris, Xerocomellus chrysenteron (Bull.) Štara. These species have a broad ecological valence. They are observed in all sites, but with different degree of abundance.

Due to the variety of soil and hydrological conditions, the settlement of symbiotrophic species related to broad-leaved forests is rather complex. Species composition of symbiotrophic species in the most favorable conditions for growth of trees, on moister and humus rich grey forest soils, usually occupied by association Quercus robur+Tilia cordata-Aegopodium podagraria, is significantly impoverished, their abundance is also minor. It corresponds with the theory of Bierkman, which suggests that the mycorrhiza-forming fungi become weaker with good support of trees with mineral elements and moisture. (Bowen, 1973; Brundrett, 2004; 2009, Bruns, 1995, 2002; Buscot, 2000; Smith, Read 1997).

The testing transect No. 1 was laid in woodland consisting of Quercus robur and Tilia cordata of vegetative origin at the age of 65-70 to study species composition of symbiotrophic species and their yield. Underbrush consists of Corylus avellana and Euonimes verrucosa L., projective cover is $70 \%$. Aegopodium podagraria prevails in the grass cover. The projective cover is about $95 \%$. The soil is heavy loamy gray forest soil, underlain by carbonate-free clay, and $\mathrm{pH}$ is 4.5 .12 species were identified in the testing area. Ten more species were revealed in the course of the route studies of the present association. These species, identified in studied association, include all above mentioned species and Cortinarius hinnuleus Fr., C.infractus (Pers.) Fr., C. rigens (Pers.) Fr., C. trivialis (J.E. Lange) A.H. Sm., Lactarius pyrogalus, L. vellereus, Leucocortinarius bulbiger (Alb. \& Schwein.) Singer. They are the fungi with broad ecological valence. They are not typical for locality under consideration. The yield of mycorrhiza-forming fungi in these localities was only U7630 g / ha. It is a minimal index for concerned forest communities.

Association of Quercus robur+tilia cordata-Carex pilosa occupies drier localities, in comparison with lipo -Quercus robur+tilia cordata-Aegopodium podagraria, related to different variety of grey forest soils. Their most common variant in the study area is a sandy loam light-gray soil formed on silicate rock detritus flask with pH from 4.2 to 4.5. The testing transect No. 2 was laid in association of Quercus robur+tilia cordata-Carex pilosa+ heterogerbosa of 
vegetative origin at the age of 65-70 to study species composition of symbiotrophic species and their yield. Projective cover of the underbrush is 55\% and consists of Corylus avellana and Euonimes verrucosa. Carex pilosa Scop prevails in the gross cover. Its projective cover is 80-90\%. 19 species of mycorrhiza-forming fungi were revealed in the testing transect No.2. 25 more species of symbiotrophic species were revealed in the course of the route studies of the present association.

These species, identified in studied association, include all above mentioned species and Amanita crocea (Quél.) Singer, A.vaginata, Boletus edulis Bull., Cortinarius anomalus, C.hinnuleus, C. infractus, C. subviolascens Rob. Henry ex Nezdojm., Lactarius fuliginosus(Fr.) Fr., L. pyrogalus, L. volemus, Russula aurea, R. chloroides (Krombh.) Bres., R. farinipes Romell, Suillellus luridus(Schaeff.) Murrill, Xerocomellus pruinatus (Fr. \& Hök) Šutara. These are widespread species with sufficiently broad ecological valence. They are not typical for locality under consideration. Cortinarius argenteolilacinus M.M. Moser, Secr. ex J.E. Lange C. caerulescens(Schaeff.)Fr., C. citrinus J.E. Lange ex P.D.Orton should be noted as rare species identified only in these conditions. The yield of mycorrhiza-forming fungi in these localities was $30650 \mathrm{~g} / \mathrm{ha}$, i.e. it is near to the average index for broad-leaved forests.

The maximum abundance and variety of symbiotrophic species for broadleaved forests is typical for association of Quercus robur+Tilia cordata-Carex pilosa on light loam gray forest soils with $\mathrm{pH}$ of 6.5-7. They are formed on the slopes of river valleys on the yields of marl`s carbonate rock. Strengthening the process of mycorrhiza-forming in these conditions is because the phosphorus there is tied by calcium ions and passes in forms which are unavailable for plants (Remezov, Pogrebnyak, 1965). Mycorrhiza-forming fungi are capable to accumulate this element in its mycelium and transfer it in the process of symbiotic relationship to trees, contributing to their growth in these conditions (Smit, Rid, 1997).

The testing transect No. 3 was laid to study symbiotrophic species in considered coil conditions. The tree stratum consists mainly of Qercus robur of coppice regeneration at the age of 60-45 with a slight impurity of Tilia cordata. Underbrush has been formed by Corylus avellana with the projective cover of $40-50 \%$; the grass cover is with the projective cover Carex pilosa of $60-70 \%$. The soil is forest dark grey; $\mathrm{pH}$ is 7 , underlain by marl. The transect is located on the slope of the valley of the river Sura with steepness of 15-20 degrees. 25 species of symbiotrophic species were revealed in the course of the stationary studies. They included all species with broad ecological valence, identified in transects No.1 and No.2.

58 more species were revealed in the course of the route studies. Among them, first of all, it is necessary to specify calciphilous highly specialized species, which are found mainly on calcareous soils in the conditions of the region under study. They include Amanita strobiliformis, (Paulet ex Vittad.) Bertill., Butyriboletus fechtneri(Velen.) Arora \& J.L. Frank, Caloboletus radicans (Pers.) 
Vizzini, Cortinarius sodagnitus Rob. Henry, C. sulfurinus Rob. Henry, Hemileccinum depilatum (Redeuilh) Šutara, Hemileccinum impolitum (Fr.) Šutara, Hygrophorus arbustivus Fr., H. dichrous Kühner\&Romagn., H. eburneus (Bull.) Fr., H. penarius Fr., H. russula (Schaeff.) Kauffman, Lactarius acerrimus Britzelm., Leccinellum crocipodium (Letell.) Della Maggiora\&Trassin., Suillellus luridus (Schaeff.) Murrill. In associations Quercus robur+Tilia cordata-Carex pilosa adapted to grey forest soils, underlain by cretaceous marls, the yield of symbiotrophic species achieves maximum of the considered forest type and equals to $49500 \mathrm{~g} / \mathrm{ha}$.

Abundant species composition is characteristic of the testing transect No.4. In these conditions, there is maximum diversity of the studied fungi. It is confirmed by monitoring on the regular routes. 67 species, except for the specified in the Table, of symbiotrophic species were revealed in alluvial broadleaved forests, associated with grey faintly acid and dark grey forest soils. There are a lot of rare fungi, widespread only in considered ecotopes.

Broad-leaved forests in the area are common not only in the watersheds but also in the floodplains. The maximum abundance and diversity of mycorrhiza-forming fungi in these conditions is characteristic of broad-leaved forests, adapted in well-drained slightly acidic and neutral alluvial sandy soil. They are spread along the high banks of cutoff lakes. High levels of $\mathrm{pH}$ of 6-6.5 are not associated with underlying rocks, and with high levels groundwater saturated by carbonates, the $\mathrm{pH}$ of which is usually 7-7.5.

The strengthening mycorrhizal formation in these ecotopes can also be associated with a strong ferritization of sands underlying soil. They are saturated with ferric carbonate due to the hardness of close-lying groundwater. The content of the last-mentioned one has a negative effect on the growth of autotrophic plants (Remezov, Pogrebnjak, 1965):). Iron salts have a negative impact on herbaceous plants, and therefore the grass cover in these forests is strongly partly stocked. It is also favorable for mycorrhiza-forming fungi (Burova, 1976).

The transect No. 4 was laid to study mycorrhiza-forming fungi in these conditions. Forest consists of Qercus robur and Tilia cordata of coppice regeneration at the age of 65-80. Underbrush has been formed by brier and Euonimes verrucosa. Its projective cover does not exceed 30\%. Carex pilosa prevails in the grass cover. Its projective cover in different parts of transect is 40$60 \%$. The soil is sandy loam gray forest sail; $\mathrm{pH}$ is 5.5 , underlain by ferruginous alluvial sands. The transect is located on the elongated ridge in the Sura River valley between the former riverbed and sedge fen. Groundwater occurrence level is $1.7 \mathrm{~m}$. These ecotopes are characterized by high abundance and diversity of mycorrhizal fungi (Table 1). 87 species of mycorrhizal fungi were revealed in these ecotopes. 27 species are presented on the testing transect.

As well as on the gray forest loamy soils underlain by marl, calciphilous species are found there. However, only a few of them are common for these ecotopes. They are Butyriboletus fechtneri, Caloboletus radicans (Pers.) Vizzini, Cortinarius sodagnitus, Hemileccinum depilatum, Lactarius acerrimus, 
Leccinellum crocipodium, Suillellus luridus. Some species which are typical for the broad-leaved forests on gray forest soils is omitted under these conditions. Some of them are rare - Amanita strobiliformis, H. penarius, H. russula and widespread - L. volemus, Russula aurea. 16 species are specific for the floodplain broad-leaved forests. Most of them are rare, for example Suillellus rhodoxanthus (Krombh.) Blanco-Dios and Rubinoboletus rubinus (W.G. Sm.) Pilát \& Dermek listed in the Red-book of Russia (2008), as well as Suillellus rhodopurpureus (Krombh.) Blanco-Dias, Cortinarius caesiocortinatus Jul. Schäff., Rubroboletus satanas (Lenz) Kuan Zhao \& Zhu L. Yang, which are listed in the red-book of the Penza region. The species $C$. balteatoalbus Rob. Henry, C. rubellus Cooke, C. callochrous (Pers.) Gray, Entoloma lividoalbum (Kühner \& Romagn.) Kubička, Tricholoma lascivum (Fr.) Gillet, T. orirubens Quél., T. ustaloides Romagn., Rheubarbariboletus armeniacus (Quél.) Vizzini, Simonini \& Gelardi are also rare, but they don't have a conservation status.

Described ecotopes have a large value from the protection of basidial macromycetes point of view. In the terms of collecting area of the Volga river, they are easternmost point of distribution most of the South-European nemoral species. Similar ecotopes of the last one are registered in Volgo-Ahtubinskoi flood-plain in the Volgograd region (Rebriev et al. 2012).

Pasture and the consequent trampling down of the underbrush and sold formation influence on settlement of symbiotrophic species. Species diversity of mycorrhiza-forming fungi in similar clear-boled forests of a park type is reduced. Large-fruited species, whose basidiomes easily pass through a dense sod that increase its abundance mainly develop in these conditions. They are presented by B. reticulatus, Hebeloma sinapizans, Neoboletus erythropus, Rubinoboletus rubinus, Russula pseudointegra, Xerocomellus pruinatus on acid light gray forest sandy soils as well as some species that grow under the forest canopy on soils with a $\mathrm{pH}$ of 6 or higher, for example Butyriboletus fechtneri, Caloboletus radicans, Hemileccinum impolitum, Suillellus luridus, S. rhodopurpureus, Rubroboletus satanas will join them in flood-lands.

\section{CONCLUSIONS}

Broad-leaved forests among the forest community of the considered area have the richest species diversity of mycorrhiza formation fungi, which are presented by 164 species.

Due to diversity of soil and hydrological conditions, the settlement of symbiotrophic species associated with broad-leaved forests seems rather complex. Impoverished species diversity of symbiotrophic species is typical of Quercus robur+Tilia cordata on acid soils with $\mathrm{pH}$ from 4.3 to 4.5 and more abundant for broad-leaved forests soils with $\mathrm{pH}$ 6-7.

The broad-leaved forests in flood-plain of water-collecting area of the Volga river are easternmost point of distribution most of the South-European nemoral species (ad some examples - species names). 


\section{REFERENCES}

Bakker, H.C. (2005): Diversity in Leccinum. A molecular phylogenetic approach. $160 \mathrm{p}$.

Bedenko, E.P. (1979): Macromycetes of Belgograd region // Novosti sistematiki nizshih rasteniy. 16: 33-42 (in Russian)

Brundrett, M.C. (2004): Diversity and classification of mycorhizal associations. Biol. Rev. 79: 473-495

Brundrett, M.C. (2009): Mycorrhizal associations and other means of nutrition of vascular plants: understanding global diversity of host plants by resolving conflicting informations and developing reliable means of diagnosis. Plant Soil. 320:37-77

Bruns, T. D. (1995). Thoughts on the processes that maintain local species diversity of ectomycorrhizal fungi. Plant Soil. 170:63-73.

Bruns, T.D., Bidartondo, M.I., Taylor, L.D. (2002): Host Specificity in Ectomycorrhizal Communities: What Do the Exceptions Tell Us INTEG. AND COMP. BIOL. 42:352-359

Bowen, G.D. (1973): Mineral nutrition of ectomicorrhizae und Ectomycorrhiza, Their Ecology and Physiology., Ed. Marx G.C., Kozlowsky T.T. AP.151-205.

Buscot, F, Munch JC, Charcosset JY, Gardes M, Nehls U, Hampp R. (2000): Recent advances in exploring physiology and biodiversity of ectomycorrhizas highlight the functioning of these symbioses in ecosystems. FEMS Microbiology Reviews. 24:601614.

Burova, L.G., (1976): Influence of moss and grass cover on the development and distribution of macromycetes in broad-leaved spruce forests of the Moscow region.II //Mycologia i Phytophathologia. 10(2): 81-85 (in Russian).

Ganzha, R.V. (1960): Pileate fungi of oak forestes of river-valley Vorksla // Botanicheckiy zhurnal. 45(5): 758-764 (in Russian).

Index Fungorum (2016) lndexfungorum.org/names/names.asp Accessed 18 november 2016.- web source , on the end of the list www. Indexfungorum...

Ivanov, A.I.(1987): Macromycetes of oak in Penza region. II. Symbiotrophic species //Mycologia i Phytophathologia. 21(5): 419-424 (in Russian).

Ivanov, A.I. (1992): Biota of macromycetes of right-bank forest-steppe of the Volga region, Diss. Moscow. 289 (in Russian).

Ivanov, A.I., Vlasov, A.S., Vlasova, T.G., Sashenkova, S.A. (2012): Woody plants in the Penza region. Penza: RIO PGSHA. 252 (in Russian).

Ivanov, A.I. (1994): Macromycetes of pine forests of forest-steppe of the right bank of the Volga // Mycologia i Phytophathologia. 28(2):7-15. (in Russian).

Knudsen, H., Vesterholt, J. (2008): Funga Nordica Agaricoid, Boletoid and Cyphelloid genera. Copengagen: Nordvamp. 966.

Milkov, F.N. (1953): Middle Volga. Moscow: AN USSR publ. 153 (in Russian).

Moser, M. (1978): Die Rohrlinge und Blatterpilze. Kleine kriptogamenflora, lib/2.Studgart, Nev York: Gustav Ficher Verlag. 553.

Muñoz J.A. (2005): Boletus s.l. Edizioni Candusso. 951 .

Rebriev, Yu. A., Rusanov, T.S., Bulgacov, T. Yu., Svetasheva, I.V., Zmitrovich, I.V., Popov, E.S .(2012): Mycobiota of the arid the south-west of Russia. Rostov na Donu: Isdatelstvo Yznogo federalnogo universiteta. 88 (in Russian).

Red-book of the Penza region. Fungi, lichens, mosses, vascular plants, publ.2 (2013): Penza: OAO Penzeckaja pravda. 300 (in Russian). 
Red-book of the Russian Federation (plants and fungi) (2008): Moscow:TNK KMK publ. 855 (in Russian).

Remezov, N.P., Pogrebnjak, P.S. (1965): Forestry, soil science. M.: Lesnaja promichlennost. 324 (in Russian).

Smith, S., Read D.J. (1997). Mycorrhizal symbiosys. London UK: Academic press. 605

Tedersoo, L., May, T.W., Smits, M.E. , 2010. - Ectomycorrhizal lifestile in fungi: global diversity, distribution and evolution of phylogenetic lineages. Mycorrhiza. 20: 217263

Zhakov, S.I. (1970) Climate // Nature of the Penza oblast. Saratov: Privolzyskoye kniznoe isdatelstvo. 47 - 82 (in Russian). 